\title{
Tuberculosis Treatment Outcome in a Tertiary Hospital in South Eastern Nigeria; a Five Year Retrospective Study
}

\author{
Njelita I.A, Nwachukwu C.C, Umeh U.M, Ufoaroh C.U, Eyisi I.G, Okafor D.C
}

\begin{abstract}
Tuberculosis is a leading cause of morbidity and mortality in developing countries of the world. Monitoring tuberculosis treatment outcomes is important in evaluating the effectiveness of tuberculosis control programme. This study investigated the outcome of tuberculosis treatment at Chukwuemeka Odumegwu Ojukwu University Teaching Hospital (COOUTH) in South Eastern Nigeria.

This a retrospective analysis of tuberculosis patients registered at COOUTH from January 2013 to January 2018. The secondary data was obtained from the facility central tuberculosis register, with treatment outcome and tuberculosis type categorized based on the guideline of National Tuberculosis, Leprosy and Buruli ulcer Control Programme (NTBLCP) of Nigeria. The association of treatment outcome with demographic characteristics and other clinical factors was analyzed using the Chi-square test. Out of the 578 tuberculosis patients, $\mathbf{7 4 . 2 \%}$ were successfully treated, $18.9 \%$ were lost to follow up, $5.7 \%$ died and $0.3 \%$ had treatment failure. Outcome of tuberculosis treatment was significantly associated with age, site of disease and HIV status of patients.

Tuberculosis treatment outcome in COOUTH was satisfactory. However, patients at risk of unsuccessful outcome should be identified promptly and granted appropriate support and follow-up.
\end{abstract}

Index Terms-South-Eastern Nigeria; Tuberculosis; Treatment outcome.

\section{INTRODUCTION}

Tuberculosis (TB) is a curable communicable disease caused by the bacterium mycobacterium tuberculosis, commonly

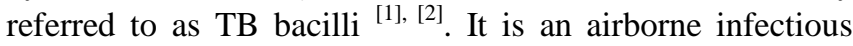
disease that primarily affects the lungs, giving rise to

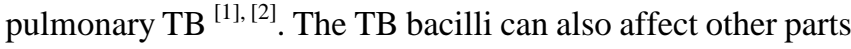

Njelita Ifeoma Anne, Department of Community Medicine and Primary Health care, Chukwuemeka Odumegwu Ojukwu University, Awka, Anambra State, Nigeria

Nwachukwu Chinyerem Cynthia, Department of Community Medicine and Primary Health care, Chukwuemeka Odumegwu Ojukwu University, Awka, Anambra State, Nigeria.

Umeh Uche Miriam, Department of Community Medicine and Primary Health care, Chukwuemeka Odumegwu Ojukwu University, Awka, Anambra State, Nigeria.

Ufoaroh Chinyelu Uchenna, Department of Internal Medicine, Chukwuemeka Odumegwu Ojukwu University Teaching Hospital, Awka/Nnamdi Azikiwe University Awka, Anambra State, Nigeria.

Eyisi Ifeanyi Gabriel, Department of Community Medicine and Primary Health care, Chukwuemeka Odumegwu Ojukwu University, Awka, Anambra State, Nigeria.

Okafor Daniel Chukwuemeka, Department of Medical Laboratory Science, Chukwuemeka Odumegwu Ojukwu University Teaching Hospital, Awka, Anambra State, Nigeria. of the body such as the lymph nodes, spine, brain, kidneys, joints etc causing extra-pulmonary $\mathrm{TB}^{[1], \text { [2] }}$. Transmission of TB is more intense in crowded, poorly ventilated places, being an airborne disease ${ }^{[1]}$.

A person can be infected with TB bacilli but show no symptoms (latent TB infection). A latent TB infection can progress to an active TB disease in the presence of immunosuppression which could be triggered by human immunodeficiency virus (HIV) infection, malnutrition, age, diabetes and cancer ${ }^{[1]}$. However, a relatively small proportion $(5-15 \%)$ of the estimated $2-3$ billion people infected with TB bacilli will develop active TB disease in their lifetime ${ }^{[3]}$.

Important challenges to TB control are HIV co-infection and emergence of drug resistance ${ }^{[4],[5]}$. HIV co-infection is the commonest and most powerful known risk factor for progression of latent TB infection to active TB disease ${ }^{[1]}$.' In Africa, HIV prevalence among TB patients is approximately $38 \%$, while it is $23 \%$ in Nigeria ${ }^{[1]}$.

According to the Global TB report of 2016 by the World Health Organization (WHO), there was an estimated 10.4 million new TB cases worldwide in 2015 , with people living with HIV accounting for 1.2 million (11\%) of the new TB cases ${ }^{[3]}$. Nigeria ranked fourth among the six countries that accounted for $60 \%$ of the new TB cases in $2015^{[3]}$. An estimated total of 1.4 million deaths due to TB occurred in 2015, making TB one of the top 10 causes of deaths worldwide ranking above HIV/AIDS as a leading cause of death from an infectious disease ${ }^{[3]}$. There was also an estimated additional 0.4 million deaths resulting from TB disease among people living with HIV ${ }^{[3]}$. The 2016 WHO TB report estimates a TB incidence of 322 per 100,000 population in Nigeria ${ }^{[3]}$.

Proper treatment of TB is aimed at curing the patient, interrupting the transmission of the $\mathrm{TB}$ bacilli to other persons, preventing relapse of $\mathrm{TB}$ and preventing development and transmission of drug resistance ${ }^{[1],[6]}$. Treatment outcome results, to a large extent, serve as an estimate of the quality of TB treatment provided by a health care system ${ }^{[6]}$.

This study assessed the outcome of TB treatment and its associated factors at Chukwuemeka Odumegwu Ojukwu University teaching hospital (COOUTH) Awka, Anambra State, South Eastern Nigeria. 


\section{MATERIALS AND METHODS}

\section{Study Area}

Chukwuemeka Odumegwu Ojukwu University teaching hospital (COOUTH) Awka is a State government owned teaching hospital located at Awka the capital city of Anambra State of Nigeria. It provides tertiary health care services to residents of Awka and its environ, including parts of Enugu and Delta States.

COOUTH Awka has a chest clinic operating under the National Tuberculosis, Leprosy and Buruli ulcer Control Programme (NTBLCP) of Nigeria. Sputum smear microscopy with Ziehl-Nielsen staining for acid-fast bacilli and Xpert MTB / RIF (a new rapid molecular test) are both used in the chest clinic for the diagnosis of TB. Radiographs and other pathological investigations are also used to support diagnosis, especially in extra pulmonary TB. The directly observed treatment short course (DOTS) strategy is adopted in patient management in this clinic.

COOUTH Awka also has a multi-disciplinary specialist clinic for HIV management, covering counseling, testing, prevention of mother to child transmission (PMTCT), and treatment in collaboration with donor agencies and in line with the National guideline.

\section{Study Design}

This is a retrospective analysis of the treatment outcome of all TB patients managed at the chest clinic of COOUTH Awka from January 2013 to January 2018.

\section{Data Collection}

The secondary data utilized for this study was obtained from the facility central TB register, a tool supplied by the National TB/Leprosy Control Programme. Data on patients diagnosed and registered for treatment were obtained from the register and entered into a proforma. The information obtained from the register included patient's age, sex, address, site of disease, patient type, result of baseline, 2nd, 5th and 6th month investigations, treatment outcome and HIV status.

\section{Data Analysis}

Data were entered into the Statistical Package for Social Sciences (SPSS) for windows version 20. Frequency tables were generated and cross tabulation of variables done. Chi-square test was used to determine the relationship between variables. The level of statistical significance was set at $\mathrm{p}$-value of $\leq 0.05$

Ethical clearance was sought and obtained from COOUTH Health Research Ethical Committee.

\section{Definition of Terms}

According to the NTBLCP guideline ${ }^{[1]}$ of Nigeria, the following clinical case, patient type and treatment outcome standard definitions were used:

\section{Disease Classification}

\section{Pulmonary TB (PTB)}

This is a form of TB that involves the lung parenchyma. Miliary TB is classified as PTB because there are lesions in the lungs as well.

\section{Extra-pulmonary TB (EPTB)}

This type of TB involves one or more organs other than the lung parenchyma, for e.g. the pleura, lymph nodes, abdomen, genitourinary tract, skin, joints and bones and / or meninges.
Both intra-thoracic tuberculous lymphadenopathy (e.g. involving the mediastinal and / or hilar lymph nodes) and tuberculous pleural effusion, when radiographic abnormalities in the lungs are absent, constitute cases of EPTB.

\section{Patient Type}

New patients

This refers to any patient diagnosed with TB who has never received treatment for $\mathrm{TB}$, or who has taken anti-TB medications for less than 4 weeks. This is irrespective of site of the disease or whether the patient was bacteriologically or clinically diagnosed.

\section{Relapse patients}

This refers to any previously treated patient who was documented as cured or treatment completed in their most recent treatment episode. They could also be bacteriologically or clinically diagnosed.

\section{Treatment after failure patients}

This refers to any previously treated TB patient who remained or became bacteriological positive at the $5^{\text {th }}$ month or later of their most recent treatment episode but now bacteriologically diagnosed with TB.

Treatment after loss to follow-up patients

This refers to any TB patient who has been on anti-TB medications for more than 4 weeks, interrupted treatment for at least 8 weeks and now is bacteriologically or clinically diagnosed with any form of TB.

\section{Other previously treated patients}

This refers to any previously treated TB patient, with an unknown or undocumented outcome for their most recent treatment episode, who is now bacteriologically or clinically diagnosed with TB.

\section{Transfer in patients}

This refers to any TB patient who has been diagnosed and registered for treatment in a facility in one local government area (LGA) and is transferred to a facility in another LGA to continue treatment.

\section{Treatment Outcomes}

\section{Cured}

This refers to a PTB patient with bacteriologically diagnosed $\mathrm{TB}$ at the beginning of treatment and who completes treatment and was bacteriologically negative in the last month of treatment and at least one previous occasion.

\section{Treatment completed}

This refers to a TB patient who completed treatment but without evidence of cure or failure.

\section{Treatment failure}

This refers to a PTB patient with bacteriologically diagnosed TB at the beginning of treatment who remained bacteriologically positive at the $5^{\text {th }}$ month or later in the course of treatment.

\section{Died}

This refers to a TB patient who dies for any reason during the course of treatment.

\section{Lost to follow- up}

This refers to a TB patient whose treatment was interrupted for 2 consecutive months or more.

\section{Transferred out}

This refers to a TB patient whose treatment outcome is 
unknown due to transfer to another treatment facility.

\section{Treatment success}

This refers to the sum total of patients who were cured and who completed treatment.

\section{RESULTS}

Table 1 shows the demographic characteristics of the patients. Majority of the patients $(28.0 \%)$ were in the age group 25 - 34 years, with males $(56.7 \%)$ more affected than females $(43.3 \%)$. Majority of the patients (54.2\%) were resident in rural areas.

Table 2 shows the distribution by disease classification, HIV status, baseline investigation and type of patient. PTB $(93.1 \%)$ occurred more than EPTB $(6.9 \%)$. A great majority of the patients $(83.9 \%)$ were new TB cases, and most (61.6\%) were bacteriologically diagnosed. Of the PTB cases, $66 \%$ were sputum smear positive. TB/HIV co- infection was present in $34.3 \%$ of cases, and $98.5 \%$ of cases had known HIV status.

Table 3 shows the distribution of TB treatment outcome. As much as $74.2 \%$ of the TB patients were successfully treated, $18.9 \%$ were lost to follow up, $5.7 \%$ died and $0.3 \%$ had treatment failure.

Table 4 shows the distribution of patients' demographic characteristics and TB/HIV status by TB treatment outcome. TB patients aged $>40$ years had a higher proportion of successful treatment $(75.4 \%)$ and death $(8.3 \%)(\mathrm{p}=0.05)$. Those aged $\leq 40$ years had a higher proportion of lost to follow up $(21.6 \%)(\mathrm{p}=0.05)$. Successful treatment was higher in patients with EPTB $(82.5 \%)$ than PTB $(73.6 \%)(\mathrm{p}=$ $0.044)$. Death was also higher in EPTB (12.5\%) than PTB $(5.2 \%)(p=0.044)$. In addition, lost to follow up was higher among PTB patients $(19.9 \%)$ than EPTB patients $(5 \%)$; and treatment failure was noted only among PTB patients $(0.4 \%)$ $(\mathrm{p}=0.044)$.

A higher proportion of patients with negative HIV result $(78.5 \%)$ had successful treatment than those with positive result $(67.7 \%)(p=0.002)$. In addition death was higher among HIV positive $(9.1 \%)$ than HIV negative (4\%) patients; lost to follow up was higher among HIV positive $(22.2 \%)$ than HIV negative $(16.1 \%)$ patients; and treatment failure occurred only among HIV positive $(1 \%)$ patients $(\mathrm{p}=0.002)$.

\section{DISCUSSION}

According to the Global TB report of 2016 by the World Health Organization (WHO) ${ }^{[3]}$, the TB treatment success rate varies from 34\% in Angola to 94\% in China, with a global average of $83 \%$. The report of 2016 also showed Nigeria had a treatment success rate of $87 \%{ }^{[3]}$. In this study, treatment success rate was $74.2 \%$. This is lower than the global average and the Nigeria rate of $83 \%$ and $87 \%$ respectively. This success rate was much higher than the rate, $29.5 \%$, in a study in a teaching hospital in Ethiopia ${ }^{[6]}$.

This could be as a result of the high transferred out rate (42\%) as noted in the study. The treatment success rate is also higher than the finding, $46.1 \%$, in a tertiary hospital in South West Nigeria ${ }^{[7]}$. This finding could be attributed to the high lost to follow up rate, $30.8 \%$, noted in the study. The success rate is equally higher than the rate, $61.3 \%$, noted in a Federal teaching hospital in the same South East Nigeria ${ }^{[8]}$. This could be as a result of a smaller sample size utilized in the study. The treatment success rate of $74.2 \%$ is also higher than the rate of $65.8 \%{ }^{[2]}$ noted in a study in a tertiary hospital in Northern Nigeria.

A proportion of $18.9 \%$ of TB patients were lost to follow up. This is comparable to that, $18.3 \%$, in Ethiopia ${ }^{[6]}$, higher than that, $14.6 \%$, in the Federal tertiary hospital ${ }^{[8]}$, and better than that in the north $(26.2 \%)^{[2]}$ and $30.8 \%$, in the South west study ${ }^{[7]}$. These differences could be attributed to variations in DOTS performance in the various study locations.

This study showed the death rate of TB patients to be $5.7 \%$. This is higher than the finding in Northern Nigeria $(1.0 \%)^{[2]}$ but lower than the finding in Ethiopia (10.1\%), South West Nigeria $(25 \%)$, and the Federal tertiary hospital $(16.2 \%)^{[6]-}$ [8].

A failure rate of $0.3 \%$ was observed in this study. This is comparable to the finding of $0.2 \%$ in Ethiopia ${ }^{[6]}$. This is however lower than the findings in the Federal tertiary hospital $(1.9 \%)^{8}$, Northern Nigeria $(6.9 \%)^{[2]}$ and South West Nigeria $(8.3 \%)^{[7]}$

A proportion of $0.9 \%$ of the TB patients were transferred out to another centre before the completion of their treatment. This is far lower than the findings in Ethiopia (42\%), South West Nigeria $(7.7 \%)$, and the other South East Tertiary hospital $(5.4 \%)^{[6]-[8]}$.

Data from this study revealed that TB/HIV co-infected cases have an increased risk of unsuccessful outcome compared with HIV negative cases. Thus, a larger proportion of HIV negative patients had successful treatment $(78.5 \%)$ than TB/HIV co-infected patients $(67.7 \%) \mathrm{p}=0.002$. The same observation were noted for mortality $(4.0 \%, 9.1 \%)$, failure $(0.0 \%, 1.0 \%)$, and lost to follow up $(16.1 \%, 22.2 \%)$ respectively $\mathrm{p}=0.002$. This is consistent with other published reports that establish $\mathrm{TB} / \mathrm{HIV}$ co-infection is associated with a poorer outcome of treatment ${ }^{[2],[7]-[11]}$.

This study demonstrated a statistically significant association between age and death as a treatment outcome. A higher proportion $(8.3 \%)$ of patients aged $>40$ years died compared to those aged $\leq 40$ years $(3.8 \%), p=0.050$. This is in agreement with findings from previous reports ${ }^{[6],[12]-[14]}$. This could be as a result of co - morbidities in older patients. This is however not the finding in the study at the federal teaching hospital in South East Nigeria.

There was also a statistically significant association between the site of the disease and treatment outcome. A greater proportion of EPTB patients were successfully treated $(82.5 \%)$ or died $(12.5 \%)$, compared with PTB patients $(73.6 \%, 5.2 \%)$ respectively, $\mathrm{p}=0.044$. A greater proportion of PTB patients had treatment failure $(0.4 \%)$, or were lost to follow up (19.9\%), compared with EPTB patients $(0.0 \%$, $5.0 \%$ ) respectively, $\mathrm{p}=0.044$. This was also not the case at the federal teaching hospital in South East Nigeria.

Unlike the findings in other studies, there is no statistically significant association between treatment outcome and factors such as sex, type of patient, place of residence and result of baseline sputum examination in this study. According to other studies, female gender ${ }^{[6],[8],[13]}$ and urban residents ${ }^{[6]}$ had higher chances of successful treatment while smear negative PTB patients had lower probability of successful outcome ${ }^{[6]}$. 
Tuberculosis Treatment Outcome in a Tertiary Hospital in South Eastern Nigeria; a Five Year Retrospective Study

Table 1: Socio-demographic characteristics of the patients

\begin{tabular}{|c|c|c|}
\hline Variables & Frequency $(n=578)$ & Percent \\
\hline $\begin{array}{c}\begin{array}{c}\text { Age } \\
\text { (years) }\end{array} \\
\end{array}$ & & \\
\hline$<15$ & 24 & 4.2 \\
\hline $15-24$ & 66 & 11.4 \\
\hline $25-34$ & 162 & 28.0 \\
\hline $35-44$ & 123 & 21.3 \\
\hline $45-54$ & 95 & 16.4 \\
\hline $55-64$ & 51 & 8.8 \\
\hline$\geq 65$ & 57 & 9.9 \\
\hline Mean \pm SD & $39.7 \pm 16.78$ & \\
\hline Sex & & \\
\hline Male & 328 & 56.7 \\
\hline Female & 250 & 43.3 \\
\hline $\begin{array}{cc}\text { Place } & \text { of } \\
\text { residence }\end{array}$ & & \\
\hline Urban & 265 & 45.8 \\
\hline Rural & 313 & 54.2 \\
\hline
\end{tabular}

Table 3: Distribution of TB treatment outcome

\begin{tabular}{lll}
\hline & Frequency $(\mathbf{n}=\mathbf{5 7 8})$ & Percent \\
\hline Cured & 178 & 30.8 \\
$\begin{array}{l}\text { Treatment } \\
\text { completed }\end{array}$ & 251 & 43.4 \\
Failure & 2 & \\
Died & 33 & 0.3 \\
Lost to follow & 109 & 5.7 \\
up & & 18.9 \\
Transferred out & 5 & 0.9 \\
*Treatment & 429 & 74.2 \\
success & & \\
\hline
\end{tabular}

*Treatment success $=$ cured + treatment completed

Table 2: Distribution by disease classification, HIV status, baseline investigation and type of patient.

\begin{tabular}{|c|c|c|}
\hline Variables & $\begin{array}{l}\text { Frequency } \\
(n=578)\end{array}$ & Percent \\
\hline \multicolumn{3}{|l|}{ Disease classification } \\
\hline РTB & 538 & 93.1 \\
\hline ЕРТВ & 40 & 6.9 \\
\hline \multicolumn{3}{|l|}{ Type of patient } \\
\hline New patients & 485 & 83.9 \\
\hline Relapse patients & 7 & 1.2 \\
\hline $\begin{array}{l}\text { Treatment after failure } \\
\text { patients }\end{array}$ & 7 & 1.2 \\
\hline $\begin{array}{l}\text { Treatment after loss to } \\
\text { follow-up patients }\end{array}$ & 28 & 4.8 \\
\hline Transfer in patients & 13 & 2.2 \\
\hline $\begin{array}{l}\text { Other previously treated } \\
\text { patients }\end{array}$ & 38 & 6.6 \\
\hline \multicolumn{3}{|l|}{ Investigation result } \\
\hline \multicolumn{3}{|l|}{$\begin{array}{l}\text { before initiation of } \\
\text { treatment }\end{array}$} \\
\hline Sputum AFB positive & 268 & 46.4 \\
\hline $\mathrm{X}-$ ray & 122 & 21.1 \\
\hline XpertMTB/RIF positive & 88 & 15.2 \\
\hline Clinically diagnosed & 85 & 14.7 \\
\hline $\begin{array}{l}\text { Transferred in without } \\
\text { evidence of baseline result }\end{array}$ & 8 & 1.4 \\
\hline Histology report & 7 & 1.2 \\
\hline \multicolumn{3}{|l|}{ HIV status } \\
\hline HIV positive & 198 & 34.3 \\
\hline HIV negative & 371 & 64.2 \\
\hline Unknown status & 9 & 1.6 \\
\hline \multicolumn{3}{|l|}{ Туре of РТВ } \\
\hline Smear positive & 355 & 66.0 \\
\hline Smear negative & 176 & 32.7 \\
\hline No baseline investigation & 7 & 1.3 \\
\hline
\end{tabular}


Table 4: Distribution by patients demographic

\begin{tabular}{|c|c|c|c|c|c|}
\hline Variables & $\begin{array}{l}\text { Successful } \\
(\%)\end{array}$ & Failure (\%) & $\begin{array}{l}\text { Death } \\
(\%)\end{array}$ & $\begin{array}{l}\text { Lost to follow } \\
\text { up (\%) }\end{array}$ & $\begin{array}{l}\text { Transferred out } \\
(\%)\end{array}$ \\
\hline Age group (years) & $X^{2}=8.601$ & $P=0.050(F)$ & & & \\
\hline$\leq 40$ & 73.4 & 0.3 & 3.8 & 21.6 & 0.9 \\
\hline$>40$ & 75.4 & 0.4 & 8.3 & 15.0 & 0.8 \\
\hline Sex & $X^{2}=6.009$ & $\mathrm{P}=0.170(\mathrm{~F})$ & & & \\
\hline Male & 73.8 & 0.0 & 5.5 & 19.2 & 1.5 \\
\hline Female & 74.8 & 0.8 & 6.0 & 18.4 & 0.0 \\
\hline Place of residence & $X^{2}=6.206$ & $\mathrm{P}=0.156$ & & & \\
\hline Urban & 78.9 & 0.4 & 4.5 & 15.8 & 0.8 \\
\hline Rural & 70.3 & 0.3 & 7.0 & 21.4 & 1.0 \\
\hline Disease classification & $\mathrm{X}^{2}=\mathbf{9 . 2 5 2}$ & $P=0.044(F)$ & & & \\
\hline PTB & 73.6 & 0.4 & 5.2 & 19.9 & 0.9 \\
\hline ЕРТВ & 82.5 & 0.0 & 12.5 & 5.0 & 0.0 \\
\hline Type of patient & $\mathrm{X}^{2}=1.098$ & $P=0.865$ & & & \\
\hline New patients & 73.6 & 0.4 & 5.8 & 19.4 & 0.8 \\
\hline Retreatment patients & 77.4 & 0.0 & 5.4 & 16.1 & 1.1 \\
\hline HIV status & $X^{2}=15.624$ & $P=0.002(F)$ & & & \\
\hline HIV positive & 67.7 & 1.0 & 9.1 & 22.2 & 0.0 \\
\hline HIV negative & 78.5 & 0.0 & 4.0 & 16.1 & 1.3 \\
\hline Туре of РТВ & $X^{2}=7.917$ & $\mathrm{P}=0.070(\mathrm{~F})$ & & & \\
\hline Smear positive & 72.4 & 0.6 & 3.9 & 21.7 & 1.4 \\
\hline Smear negative & 75.6 & 0.0 & 8.0 & 16.5 & 0.0 \\
\hline
\end{tabular}

$\mathrm{F}=$ Fisher's exact test

characteristics and TB/HIV status for treatment outcome

In conclusion, this study has demonstrated that age and HIV status of patients have statistically significant association with treatment outcomes. A high proportion of the patients $(18.9 \%)$ were lost to follow up. This calls for concern and improved health education and counseling of patients, in addition to enhanced patient tracking. TB/HIV collaborative activities should be intensified and strengthened to effectively articulate prompt efficient services for co-infected patients.

\section{COMPETING INTEREST}

Authors have declared that no competing interests exist.

\section{REFERENCES}

[1] Federal Ministry of Health: National tuberculosis, leprosy and buruli ulcer management and control guidelines. Department of Public Health, National Tuberculosis and Leprosy Control Programme (NTBLCP) (2015), $6^{\text {th }}$ edition.

[2] Ofoegbu OS, Odume BB: Treatment outcome of tuberculosis patients at National hospital Abuja Nigeria: a five year retrospective study. South African Family Practice. 2015, 57 (1):50 - 56.

[3] World Health Organisation: Global tuberculosis report 2016. www.searo.who.int/tb/documents/global-tuberculosis-report-2016/en ( Accessed 13/12/2018)

[4] Corbett EL, Watt CJ, Walker N, Maher D, Williams BG, Raviglione MC, Dye C: The growing burden of tuberculosis: global trends and interactions with the HIV epidemic. Arch Intern Med. 2003, 163: 1009-1021.

[5] Dye C, Espinal MA, Watt CJ, Williams BG: Worldwide incidence of multidrug-resistant tuberculosis. J Infect Dis. 2002, 185: 1197-1202.

[6] Tessema B, Muche A, Bekele A, .Reissig D, Emmrich F, Sack U: Treatment outcome of tuberculosis patients at Gondar University Teaching Hospital, Northwest Ethiopia. A five-year retrospective study. BMC Public Health. 2009, 9:371-8

[7] Oluwole A, Olusegun E, Lawrence M, Olujide J, Demilade O, Oladele A: Two year trend analysis of default rate in tuberculosis patients in Federal Medical Centre Ido-Ekiti, Ekiti State. Journal of Asian Scientific Research. 2013, 2(12): 798-806.

[8] Adinma ED, Iloghalu IC, Azuike EC, Obi DC, Mbanuzuru VA, Nwabueze SA Modebe IA: Outcome of Tuberculosis Treatment in Tertiary Hospital in South Eastern Nigeria. Int. Inv. J. Med. Med. Sci. 2015, 2(1): 17-22.

[9] Anunnastri S, Chetchotisakd P, Wanke C: Factors associated with treatment outcomes in PTB in northeastern Thailand. Southeast Asian J Trop Med Public Health. 2005, 36 (2): 324-30.

[10] de Albuquerque MF, Ximenes RA, Lucana-Silva N, de Saude C: Factors associated with treatment failure, drop out, and death in a cohort of tuberculosis in Rocifie, Pernambuco State, Brazil. Cad Saude Publica. 2007, 23 (7): 1573-82. 
[11] Mitike G, Kebede D, Yeneneh H: HIV infection and anti-tuberculosis drug resistance among pulmonary TB patients in Harar tuberculosis centre Ethiopia. East Afr. Med. J. 1997, 74: 154-157.

[12] Berhe G, Enquselassie F, Aseffa A: Treatment outcome of smear-positive pulmonary tuberculosis patients in Tigray region, Northern Ethiopia. BMC Public Health. 2012, 12: 537.

[13] Tuula V, Pekka H, Jukka O, Kari L, Maarit K, Petri R: Risk factors for poor Tuberculosis treatment outcome in Finland: a cohort study. BMC Public Health. 2007, 7: 291-299.

[14] Talay F, Kumbetli S, Altin S: Factors associated with treatment success for tuberculosis patients: a single centre's experience in Turkey. Jpn J Infect Dis. 2008, 61 (1): 25-30. 